\title{
Pencemaran Coliform pada Air Sumur di Sekitar Sungai Ciliwung
}

\author{
Farida Ariani ${ }^{1}$, Riris Lindiawati Puspitasari ${ }^{2}$, Taufiq Wisnu Priambodo ${ }^{3}$ \\ ${ }^{1,2,3}$ Program Studi Biologi, Fakultas Sains dan Teknologi, Universitas Al Azhar Indonesia, Jalan \\ Sisingamangaraja, Kompleks Masjid Agung Al Azhar, Kebayoran Baru, Jakarta Selatan 12110
}

Email korespondensi: riris.lindiawati@uai.ac.id

\begin{abstract}
Abstrak - Kondisi pemukiman masyarakat sekitar DAS Ciliwung yang terlihat cukup padat menjadi salah satu faktor penyebab pencemaran air sumur. Selain itu tidak teraturnya jarak antara rumah dengan sungai ataupun jarak antara satu rumah dengan rumah lainya juga berdampak pada kelestarian sungai. Ketentuan yang ideal jarak pemukiman warga dengan tepi sungai diatur dalam Peraturan Pemeritah (PP) No 38 Pasal 9 Tahun 2011 yaitu paling sedikit berjarak $30 \mathrm{~m}$ dari tepi kiri dan kanan palung sungai sepanjang alur sungai, dalam hal kedalaman sungai lebih dari $20 \mathrm{~m}$. Dari ketentuan di atas dapat diketahui kemungkinan adanya kontaminasi bakteri Coliform pada air sumur yang bersumber dari sumur di sekitar DAS Ciliwung. Oleh karena itu perlu dilakukan pengujian kualitas air sumur untuk mengetahui kelayakan dan keamanan air untuk dikonsumsi masyarakat. Penelitian ini bertujuan untuk menguji keberadaan Coliform pada air sumur di sekitar DAS Ciliwung wilayah Pejaten Timur hingga Kalibata. Metode yang dilakukan pada penelitian ini adalah penentuan jumlah koloni berdasarkan Total Plate Account (TPC) dari sumber sampel air sumur tanah warga. Berdasarkan hasil pengujian didapatkan bahwa air sumur positif mengandung bakteri Coliform. Jumlah Coliform tertinggi ditemukan di wilayah Pejaten Timur dan Condet sebanyak $9.4 \times 10^{4} \mathrm{cfu} / \mathrm{ml}$ dan $8.9 \times 10^{4} \mathrm{cfu} / \mathrm{ml}$. Sementara itu jarak sumur terdekat dengan sungai yaitu $<10 \mathrm{~m}$ juga terdapat di wilayah Pejaten Timur dan Condet
\end{abstract}

\section{Kata Kunci-Ciliwung, Air Tanah, Coliform}

Abstract - The crowd of people's residentials around Ciliwung river were known to be one of the factors that caused groundwater pollution. Beside that, the lay out of houses were also participated to the river sustainability. People built their houses without any environment considerations. They built houses near to the river. According to the local government rules Peraturan Pemeritah (PP) No 38 Pasal 9 Tahun 2011, people could built houses approximately $30 \mathrm{~m}$ to the river if it had $20 \mathrm{~m}$ in depth. Based on river pollution data, we assumed that the groundwaters probably contaminated by Coliform bacteria. This hyphotese could be analyzed using several tests in order to examine the groundwater quality. If the water quality data could be gained, so it should be informed about the appropriateness to consume their groundwater. The research was aim to analyze the Coliform that collected from groundwater around Pejaten Timur to Kalibata. The metholodology of research were using Total Plate Count (TPC) in order to quantify colony number. The microbes were isolated from 51 groundwaters around areas. Based on results, all samples from groundwaters were positively contaminated by Coliform founded in Pejaten Timur and Condet. This finding indicated that contamination level in groundwater could affect people's integument and digestive system health.

Keywords - Ciliwung, Groundwater, Coliform 


\section{PENDAHULUAN}

A ir merupakan sumber daya alam yang sangat penting bagi kehidupan manusia. Fungsi air bagi kehidupan manusia tidak dapat digantikan oleh senyawa lain. kebutuhan terhadap air terus mengalami peningkatan yang diiringi dengan pertumbuhan jumlah penduduk. Hal tersebut mengakibatkan semakin tinggi taraf kehidupan sehingga meningkatkan jumlah kebutuhan air. Pemenuhan kebutuhan akan air tersebut salah satunya melalui air sumur yang berupa sumur gali maupun sumur bor [1].

Air bersih dibutuhkan manusia untuk memenuhi kebutuhan sehari-hari. Sehingga perlu diketahui kualitas air bersih dan bisa digunakan dalam jumlah yang memadai untuk memenuhi kebutuhan tersebut. Ditinjau dari segi kualitas, terdapat beberapa persyaratan yang harus dipenuhi, diantaranya kualitas fisik, kimia, dan biologi. Kualitas fisik terdiri atas bau, warna dan rasa. Kualitas kimia terdiri atas pH dan kesadahan. Kualitas biologi yaitu air terbebas dari mikroorganisme patogen seperti bakteri kelompok Coliform antara lain Escherichia coli dan Streptococcus faecalis [2].

Pada umumnya sumber air bersih yang digunakan penduduk yang tinggal di Daerah Aliran Sungai (DAS) Ciliwung adalah air sumur berupa sumur gali dan sumur bor. Air tersebut dimanfaatkan untuk mandi, mencuci, kakus, masak dan minum [3]. Masalah utama yang harus dihadapi dalam penggunaan air sumur yang berasal dari sumur yang berada di sekitar DAS Ciliwung ialah tingkat pencemaran air. Semakin tingginya tingkat pencemaran air yang berasal dari limbah rumah tangga maupun limbah industri, mengakibatkan tingginya kontaminasi mikroorganisme terutama bakteri Coliform. Semakin tinggi tingkat kontaminasi bakteri tersebut, maka semakin tinggi resiko penyakit yang dapat ditimbulkan seperti diare, demam, kram perut, dan muntah-muntah [4].

\section{METODE PENELITIAN}

Pengambilan data sampel dilakukan di DAS Ciliwung wilayah Pejaten Timur hingga Kalibata sebanyak 4 titik yaitu Jl. Gunuk V, Jl. Klengkeng Rawajati, Jl. Kemuning IV dan Jl. AMD 28 Jakarta (Gambar 1).

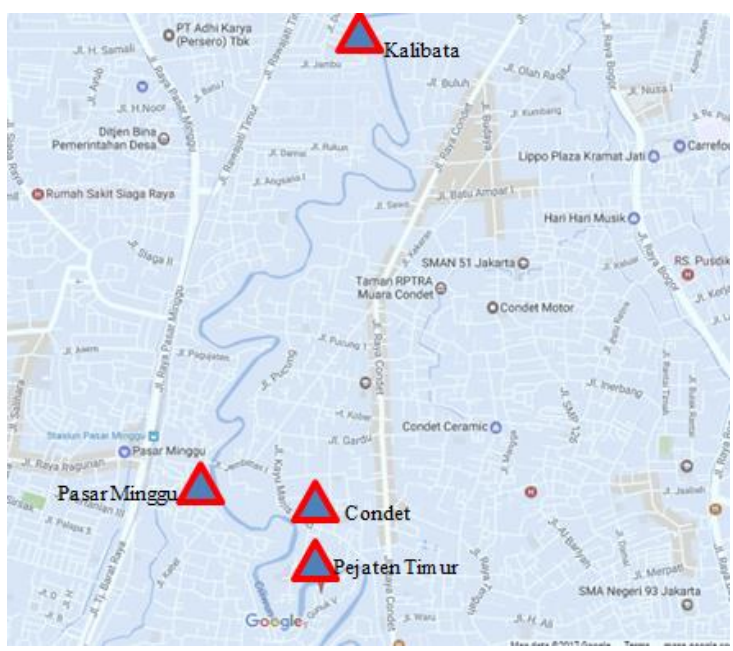

Gambar 1 Peta pengambilan sampel air sumur

Pengujian sampel dan analisis data dilaksanakan di Laboratorium Universitas $\mathrm{Al}$ Azhar Indonesia. Waktu pelaksanaan penelitian dimulai pada bulan Agustus 2016 hingga November 2016.

\section{Pengambilan Data Air Sumur}

Pengambilan data air sumur dilakukan dengan cara mengajukan beberapa pertanyaan sederhana kepada warga yang tinggal di sekitar DAS Ciliwung dalam bentuk quisioner. Hal tersebut dilakukan untuk mendapatkan informasi mengenai penyakit yang diderita oleh warga selama 3 bulan terakhir dan frekuensi penggunaan air sumur untuk kebutuhan seharihari. Jarak antara sumur dengan sungai dihitung menggunakan meteran. Dikelompokan berdasarkan Peraturan Pemeritah (PP) No 38 Pasal 9 Tahun 2011.

\section{Penentuan sampel}

Dalam penelitian ini sampel air sumur diperoleh dari sumur yang berada pada 4 lokasi. Titik tersebut ditentukan dengan teknik purposive sampling. Penentuan lokasi populasi sampel berdasarkan pengamatan deskriptif mengenai kondisi dan aktivitas warga yang tinggal di sekitar DAS Ciliwung. Setelah pengamatan dilakukan maka penentuan sampel dengan kriteria sebagai berikut,

\section{a. Kriteria Inklusi}

Kriteria inklusi adalah kriteria yang apabila terpenuhi dapat mengakibatkan calon objek menjadi objek penelitian [5]. Kriteria inklusi pada penelitian ini adalah :

1. Kebutuhan air sehari-hari bersumber dari sumber air sumur 
2. Jarak sampel air sumur dengan sungai $<30 \mathrm{~m}$

3. Adanya aktivitas tertentu

- Aktivitas sehari-hari warga

- Pabrik pembuatan makanan

- Peternak hewan (kandang hewan)

- Aktivitas ekonomi (pasar)

\section{b. Kriteria Eksklusi}

Kriteria eksklusi yaitu kriteria di luar kriteria inklusi. Kriteria eksklusi adalah kriteria yang apabila dijumpai menyebabkan objek tidak dapat digunakan dalam penelitian. Kriteria eksklusi pada penelitian ini adalah :

1. Air sungai digunakan untuk MCK, masak, mandi dan minum.

2. Tidak bersedianya warga untuk memberikan sampel air sumur.

\section{Pengambilan Sampel}

Pengambilan sampel air sungai dilakukan dengan metode pengambilan sampel sesaat (grab sample). Sampel sesaat atau grab sample yaitu sampel yang diambil secara langsung dari sumber air sumur. Sampel tersebut hanya menggambarkan karakteristik air pada saat pengambilan sampel [6]. Pengukuran temperatur air, $\mathrm{pH}$, EC dan TDS bertujuan untuk menenentukan kualitas air sumur. Pengambilan sampel dilakukan dengan mengunjungi rumah warga yang dijadikan pada pukul 06:00-10:00 pagi. Pengukuran tempratur dan $\mathrm{pH}$ dilakukan di 4 titik lokasi.

\section{Pengujian Bakteri Coliform}

Coliform merupakan bakteri fekal dan non fekal. Prinsip penentuan keberadaan bakteri Coliform ditandai dengan terbentuknya gelembung gas pada tabung Durham setelah diinkubasi pada media yang sesuai. Pada pengujian ini dilakukan dengan dua tahap yaitu, Uji Praduga (Presumptive Test) dan Uji Konfirmasi (Confirmative Test).

\section{Uji Praduga (Presumptive Test)}

Pada uji ini dilakukan pengenceran sampel dalam akuades steril dengan pengenceran $10^{-1}$, $10^{-2}, 10^{-3}$. Sebanyak 9 tabung berisi media Lactose Broth (LB) yang di dalamnya terdapat tabung Durham terbalik. Sampel air dari tiap pengenceran sebanyak $1 \mathrm{ml}$ dimasukkan ke dalam tabung yang berisi media dengan 2 kali pengulangan.
Seluruh tabung diinkubasi selama 24--48 jam dengan suhu $37^{\circ} \mathrm{C}$, setelah 24 jam dicatat jumlah tabung yang membentuk gas pada setiap pengenceran.

\section{Uji Konfirmasi (Confirmative Test)}

Untuk uji konfirmasi dilakukan dengan cara memindahkan sebanyak 1 ose dari tiap tabung yang membentuk gas pada media LB ke dalam tabung yang berisi $10 \mathrm{ml}$ media Brilliant Green Lactose Broth (BGLB) yang didalamnya terdapat tabung Durham diletakkan terbalik. Tabung diinkubasi pada suhu $37^{\circ} \mathrm{C}$ selama $24-$ 48 jam. Jika ada gas yang terbentuk maka mengkonfirmasi dugaan adanya bakteri Coliform pada sampel air sumur. Kemudian dicatat jumlah tabung yang membentuk gas.

\section{Pengujian Angka Lempeng Total}

Sebanyak $1 \mathrm{ml}$ larutan dari tiap tabung yang positif pada uji praduga dan uji konfirmasi dengan pengenceran $10^{-2}$ dan $10^{-3}$ dimasukkan ke dalam media Nutrient Agar (NA) $15 \mathrm{ml}$ dengan 2 kali pengulangan. Kemudian selama 24 - 48 jam kultur diinkubasi pada suhu $37^{\circ} \mathrm{C}$ dengan posisi terbalik. Selanjutnya jumlah koloni yang tumbuh pada tiap cawan petri dihitung dan diamati morfologinya. Angka total bakteri dalam $1 \mathrm{ml}$ sampel adalah dengan perhitungan,

$$
\begin{gathered}
\mathrm{Fp}=\frac{1}{\text { tingkat pengenceran }} \\
\text { Jumlah koloni }(\mathrm{cfu} / \mathrm{ml})=\frac{\Sigma \text { koloni } x F p}{V}
\end{gathered}
$$

Fp : Faktor pengenceran

$\mathrm{V}$ : Volume inokulasi ke cawan

Hasil perhitungan kemudian dibandingkan dengan Standar Nasional Indonesia SNI No. 01-3553 tahun 2006 yaitu cemaran mikroba dalam air sebanyak $1.0 \times 10^{2}$.

\section{HASIL DAN PEMBAHASAN}

\section{Pengambilan Data Lapangan}

Kuisiner dilakukan terhadap 15 responden. Dari hasil kuisioner terdapat 8 responden yang mengalami pilek, batuk, demam, pusing dan 7 responden lainya gatal-gatal. Menurut pengakuan beberapa responden, gatal-gatal 
yang dialami berasal dari air sumur yang digunakan untuk MCK. Seluruh responden mengatakan bahwa sumber air yang digunakan dalam memenuhi kebutuhan sehari-hari bersumber dari air sumur.

Pengambilan data juga dilakukan dengan mencatat jarak antara sumur dengan sungai serta kedalamannya. Terdapat 51 sumur dari 4 lokasi sampling dengan data sebagai berikut,

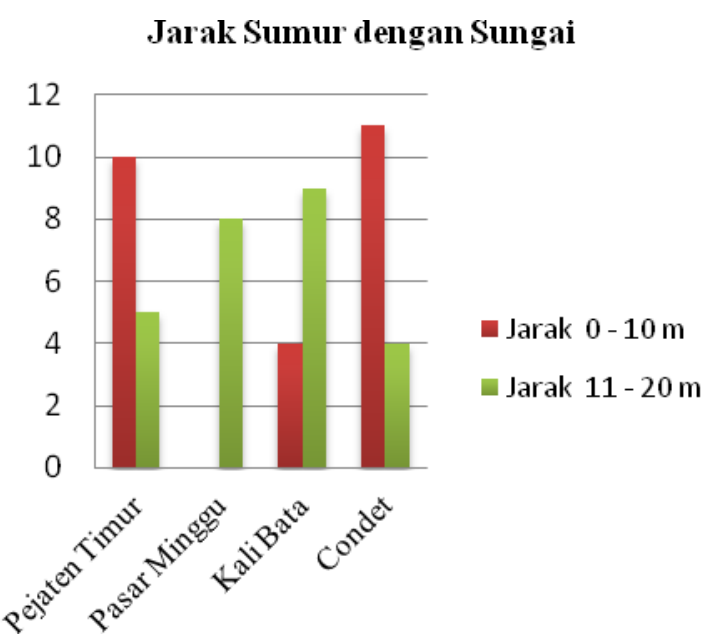

Gambar 2 Jarak sumur dengan sungai pada 4 titik sampling.

Hasil penghitungan jarak menunjukkan bahwa dari 51 sumur yang terdapat dalam pengambilan data lapangan sebanyak 25 sumur berjarak $0-10 \mathrm{~m}$. Sedangkan 26 sumur lainya dengan jarak 11 - $20 \mathrm{~m}$ (Gambar 2). Berdasarkan Peraturan Pemeritah (PP) No 38 Pasal 9 Tahun 2011 dimana paling sedikit berjarak $30 \mathrm{~m}$ dari tepi kiri dan kanan palung sungai sepanjang alur sungai. Pemukiman warga yang tinggal di sekitar DAS Ciliwung dengan jarak tersebut dapat dikatakan tidak sesuai dengan PP No 38 Pasal 9 Tahun 2011. Hal ini terjadi akibat terus meningkatnya jumlah penduduk sehingga ketidakdisiplinan masyarakat dalam mendirikan lahan pemukiman.

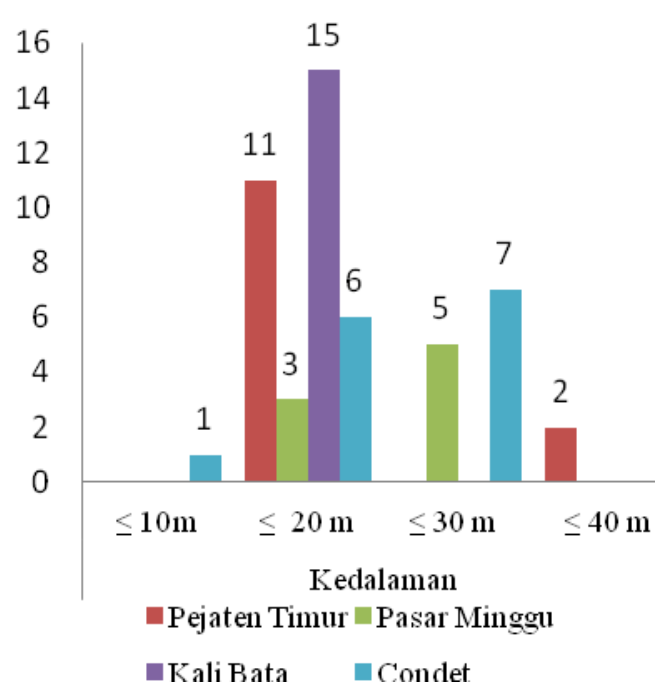

Gambar 3 Kedalaman sumur pada 4 titik sampling.

Hasil penghitungan terhadap kedalaman sumur dari setiap titik menunjukan hasil yang berbeda. Menurut informasi yang didapat dari warga yaitu kedalaman sumur sesuai dengan kondisi lingkungan sekitar. Jika lingkungan sekitar sumur kurang bersih dan sangat dekat dengan pembuangan limbah, maka sumur yang dimiliki juga semakin dalam. Hal tersebut bertujuan agar sumber air sumur yang dimiliki dapat menyerap air bersih dari dasar tanah. Wilayah yang memiliki kedalaman sumur sama adalah Kalibata. Terdapat 15 sumur dengan kedalaman yang sama yaitu $20 \mathrm{~m}$ dari permukaan. Sedangan ketiga titik lainya memiliki kedalaman sumur yang berbeda-beda (Gambar 3 ). Terdapat 1 sumur yang tidak dapat diakses oleh peneliti untuk diukur kedalaman dan diambil sampel airnya sehingga jumlah sumur menjadi 50 sumur.

\section{Temperatur dan pH Air sumur}

Temperatur merupakan salah satu faktor yang penting dalam menguji kualitas air. Hal tersebut disebabkan dapat mempengaruhi proses fisik, kimia dan biologi di dalam air [6]. Sedangkan derajat keasaman $(\mathrm{pH})$ menunjukkan tingkat keasaman atau alkalinitas pada suatu cairan dan mewakili konsentrasi ion hidrogen alkali [7]. 


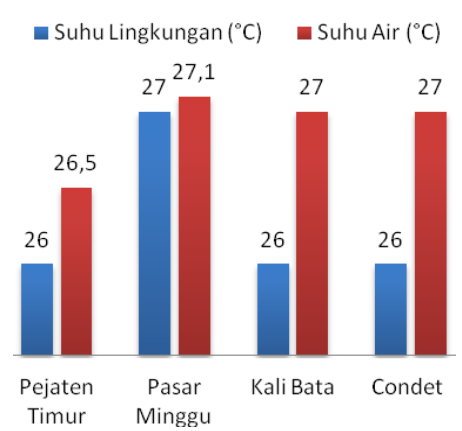

Gambar 4 Temperatur $\left({ }^{0} \mathrm{C}\right)$ air sumur di kawasan Pejaten timur hingga Kalibata.

Hasil Pengukuran temperatur lingkungan di sekitar DAS Ciliwung menunjukan bahwa suhu berkisar $26-27{ }^{\circ} \mathrm{C}$, sedangkan untuk temperatur air sama dengan temperatur lingkungan yaitu 26-27 ${ }^{\circ} \mathrm{C}$ (Gambar 4). Hasil di atas menunjukan nilai yang tidak berbeda nyata. Dalam Peraturan Menteri Kesehatan No. 416 Tahun 1990, batas maksimum temperatur adalah 30 ${ }^{0} \mathrm{C}$, sehingga nilai temperatur di lokasi penelitian masih dalam kisaran normal[8]. Setiap wilayah memiliki temperatur yang berbeda, hal ini disebabkan oleh faktor antopogen (aktivitas manusia). Aktivitas tersebut termasuk pembuangan limbah ke sungai sehingga mempengaruhi penyerapan air pada sumur air di pemukiman warga[9].

Analisa terhadap pengukuran $\mathrm{pH}$ menunjukan bahwa nilai $\mathrm{pH}$ bekisaran 6,07-6,95. Derajat keasaman $(\mathrm{pH})$ tertinggi terdapat di daerah Condet, yaitu 6,95. Nilai $\mathrm{pH}$ terendah terdapat di wilayah Kalibata yaitu 6,07 (Gambar 5). Tingginya nilai $\mathrm{pH}$ di wilayah Condet disebabkan adanya aktivitas ekonomi masyarakat yaitu pabrik tahu dan pembuangan limbah yang masuk ke dalam sungai.Terjadinya perubahan $\mathrm{pH}$ dapat dipengaruhi oleh senyawasenyawa yang dibuang ke sungai.

Derajat Keasaman $(\mathrm{pH})$

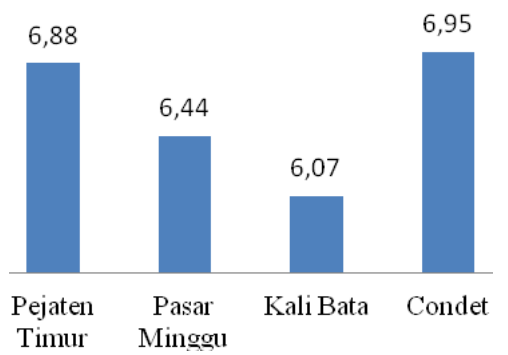

Gambar 5 Derajat keasaman (pH) air sumur dari kawasan Pejaten timur hingga Kalibata.
Derajat keasaman $(\mathrm{pH})$ merupakan salah satu faktor utama yang mempengaruhi kualitas air. Hal tersebut disebabkan karena sebagian besar biota air sangat sensitif terhadap perubahan $\mathrm{pH}$ [10]. Nilai batas $\mathrm{pH}$ untuk air sumur dalam Peraturan Menteri Kesehatan No 492/Menkes/Per/IV/2010 yaitu 6,5 - 8,5 sehingga dari hasil pengukuran dapat dinyatakan bahwa $\mathrm{pH}$ air sumur termasuk dalam taraf normal dan aman untuk digunakan[11].

\section{Angka Lempeng Total}

Berikut merupakan hasil penentuan jumlah koloni berdasarkan penghitungan angka lempeng total.

Tabel 1. Hasil Pengujian Angka Lempeng Total pada Media BGLB

\begin{tabular}{cccc}
\hline & Angka & Standar & \\
\cline { 2 - 3 } Sampel & $\begin{array}{c}\text { Lempeng } \\
\text { Total } \\
(\mathrm{cfu} / \mathrm{ml})\end{array}$ & Koloni/ml) & Keterangan \\
\hline PT 1 & $8.1 \times 10^{3}$ & $1.0 \times 10^{2}$ & TMS \\
PT 1.1 & $9.1 \times 10^{3}$ & $1.0 \times 10^{2}$ & TMS \\
PT 2 & $9.4 \times 10^{4}$ & $1.0 \times 10^{2}$ & TMS \\
PT 2.2 & $7.6 \times 10^{4}$ & $1.0 \times 10^{2}$ & TMS \\
PM 1 & $1.21 \times$ & $1.0 \times 10^{2}$ & TMS \\
PM 1.1 & $8.4 \times 10^{4}$ & $1.0 \times 10^{2}$ & TMS \\
PM 2 & $7.3 \times 10^{4}$ & $1.0 \times 10^{2}$ & TMS \\
PM 2.1 & $5.1 \times 10^{4}$ & $1.0 \times 10^{2}$ & TMS \\
KB 1 & $3.1 \times 10^{3}$ & $1.0 \times 10^{2}$ & TMS \\
KB 1.1 & $3.2 \times 10^{3}$ & $1.0 \times 10^{2}$ & TMS \\
KB 2 & $7.6 \times 10^{4}$ & $1.0 \times 10^{2}$ & TMS \\
KB 2.1 & $5.4 \times 10^{4}$ & $1.0 \times 10^{2}$ & TMS \\
C 1 & $6.5 \times 10^{3}$ & $1.0 \times 10^{2}$ & TMS \\
C 1.1 & $7.6 \times 10^{3}$ & $1.0 \times 10^{2}$ & TMS \\
C 2 & $8.1 \times 10^{4}$ & $1.0 \times 10^{2}$ & TMS \\
C 2.2 & $8.9 \times 10^{4}$ & $1.0 \times 10^{2}$ & TMS \\
\hline
\end{tabular}

Standar menurut SNI No. 01-3553 tahun 2006 Keterangan : TMS (Tidak Memenuhi Syarat)

Pada tabel 1 terlihat bahwa seluruh sampel memiliki nilai ALT melebihi batas cemaran mikroba menurut Standar Nasional Indonesia (SNI) No. 01-3553 tahun 2006 yaitu lebih dari $3,1 \times 10^{3} \mathrm{cfu} / \mathrm{ml}$. Wilayah Kalibata memiliki jarak sumur ke sungai sejauh 11-20 m yang terkait dengan rendahnya jumlah koloni bakteri Coliform pada wilayah tersebut. Rendahnya 
jumlah koloni dibanding wilayah lain disebabkan letak sumur yang tidak begitu dekat dengan sungai, sehingga cemaran bakteri Coliform dari limbah yang dibuang ke sungai tidak begitu tinggi mencemari air sumur warga [12].

Cemaran Coliform tertinggi pada sampel PT 2 (Pejaten Timur) dan C 2.2 (Condet). Tingginya cemaran Coliform pada kedua wilayah tersebut disebabkan adanya aktivitas ekonomi masyarakat yaitu pabrik pembuatan tahu. Jarak antara pabrik tahu dengan rumah warga cukup dekat sehingga, limbah yang dihasilkan dari pabrik tersebut mencemari air sumur [13].

Selain pengaruh aktivitas masyarakat yang ada wilayah tersebut, jarak antara sungai dan sumur juga mempengaruhi tingginya ALT. Pada wilayah Pejaten Timur jarak sumur dengan sungai 0-10 m yaitu sebanyak 10 sumur dari 15 sumur yang ada. Sedangkan pada wilayah Condet jarak antara sumur dengan sungai sebanyak 11 yang berjarak $0-10 \mathrm{~m}$ dari 15 sampel sumur.

\section{KESIMPULAN}

Jumlah koloni Coliform tertinggi terdapat pada wilayah Pejaten Timur dan Condet yaitu sebanyak $9.4 \times 10^{4} \mathrm{cfu} / \mathrm{ml}$ dan $8.9 \times 10^{4} \mathrm{cfu} / \mathrm{ml}$. Jarak sumur dengan sungai terdekat yaitu 0-10 $\mathrm{m}$ juga terdapat di wilayah Pejaten Timur dan Condet.

\section{UCAPAN TERIMA KASIH}

Penelitian dapat terselenggara atas pendanaan dari Grant Internal LP2M UAI dan Perusahaan Gas Negara (PGN). Dukungan pihak Kodam Jaya dalam mendampingi peneliti di lapangan.

\section{DAFTAR PUSTAKA}

[1] D. Hendrawan. Jurnal Ilmu-ilmu Perairan dan Perikanan Indonesia, 15. 2, 2008

[2] S. Yudo, N.I. Said. J. Tek. Lingk, 19. 1, 2018

[3] A.D. Astuti, B. Iswanto, B. Somantri. J. Tek. Lingk, 4. 3, 2008

[4] J. Sudarso, Y. Wardiatno, D.D. Setiyanto, W. Anggraitoningsih. J. Manusia dan Lingkungan, 20.1, 2013

[5] K. Bantas, H. Koesnanto, B. Moelyono. J. Kes. Mas. Nas, 7.6, 2013

[6] H. Effendi, Telaah Kualitas Air, Kanisius, Yogyakarta, 2003

[7] H. Soewandita, N. Sudiana. J. Air. Ind, 6.1, 2010

[8] A. B. Sujati, A. Priyono, S. Badriyah. Media Konservasi, 22.2, 2017

[9] R.M. Flamencya, Endrotomo. J. Sains dan Seni Pomits, 6.2, 2017

[10] V. Joharama , E. Riani, M. Yani, J. Pengelolaan Sumberdaya Alam dan Lingk, 8.1, 2018

[11] M. Raini, A. Isnawati, Kurniati. Media Litbang. Kes, 14.3, 2004

[12] T. Khomariyatika, E.T. Pawenang. J. Kemas, 7.1, 2011

[13] O.M. Heluth. J. MKMI, 2013 